\title{
Ocean acidification affects growth but not nutritional quality of the seaweed Fucus vesiculosus (Phaeophyceae, Fucales)
}

\author{
Lars Gutow* , Mohammed Mofizur Rahman, Kevin Bartl, Reinhard Saborowski, Inka Bartsch, Christian Wiencke \\ Alfred Wegener Institute, Helmholtz Centre for Polar and Marine Research, Box 120161, 27515 Bremerhaven, Germany
}

\section{A R T I C L E I N F O}

\section{Article history:}

Received 3 December 2013

Received in revised form 3 January 2014

Accepted 6 January 2014

Available online $\mathrm{xxxx}$

\section{Keywords:}

Climate change

Density effects

Elemental composition

Grazers

Seaweeds

Species interactions

\begin{abstract}
A B S T R A C T
Understanding the ecological implications of global climate change requires investigations of not only the direct effects of environmental change on species performance but also indirect effects that arise from altered species interactions. We performed $\mathrm{CO}_{2}$ perturbation experiments to investigate the effects of ocean acidification on the trophic interaction between the brown seaweed Fucus vesiculosus and the herbivorous isopod Idotea baltica. We predicted faster growth of $F$. vesiculosus at elevated $\mathrm{CO}_{2}$-concentrations and higher carbon content of the algal tissue. We expected that I. baltica has different consumption rates on algae that have been grown at different $\mathrm{CO}_{2}$ levels and that the isopods remove surplus carbon metabolically by enhanced respiration. Surprisingly, growth of F. vesiculosus as well as the $\mathrm{C}: \mathrm{N}$-ratio of the algal tissue were reduced at high $\mathrm{CO}_{2}$-levels. The changes in the elemental composition had no effect on the consumption rates and the respiration of the herbivores. An additional experiment showed that consumption of $F$. vesiculosus by the isopod Idotea emarginata was independent of ocean acidification and temperature. Our results could not reveal any effects of ocean acidification on the per capita strength of the trophic interaction between F. vesiculosus and its consumers. However, reduced growth of the algae at high $\mathrm{CO}_{2}$-concentrations might reduce the capability of the seaweed to compensate losses due to intense herbivory.
\end{abstract}

(C) 2014 Elsevier B.V. All rights reserved.

\section{Introduction}

Ocean acidification has substantial effects on the performance of a great variety of marine organisms (Chan and Conolly, 2013; Harvey et al., 2013; Kroeker et al., 2010, 2013; Widdicombe and Spicer, 2008). Negative effects of ocean acidification arise from enhanced dissolution of carbonate shell structures in calcifying organisms as well as from impaired extra-cellular acid-base regulation in marine animals (Hall-Spencer et al., 2008; Pörtner et al., 2004). In autotrophic organisms the predicted shift in the seawater carbonate chemistry can facilitate the acquisition of inorganic carbon for photosynthesis (Hurd et al., 2009) allowing for the allocation of more energy into somatic processes. Accordingly, elevated growth has been observed in non-calcifying seaweeds and seagrasses under conditions of ocean acidification (Zimmermann et al., 1997; Zou, 2005). However, the responses of non-calcifying seaweeds to ocean acidification are inconsistent and may vary between closely related species or even within species among different developmental stages (Olischläger et al., 2012; Swanson and Fox, 2007). Additionally, subtle interactions of ocean acidification with other environmental variables, such as temperature, complicate the prediction of effects of ocean acidification on seaweeds (Martin and Gattuso, 2009; Sarker et al., 2013).

\footnotetext{
* Corresponding author.

E-mail address: Lars.Gutow@awi.de (L. Gutow).
}

Recent studies have predominantly addressed the direct effects of ocean acidification on marine species. However, indirect effects of ocean acidification, which are mediated through altered species interactions, have received much less attention (Falkenberg et al., 2013a,b; Poore et al., 2013). Indirect effects can modify single species responses, and are thus crucial for a comprehensive understanding of the implications of global climate change for the structure and functioning of marine ecosystems (Alsterberg et al., 2013). Ocean acidification may affect the outcome of species interactions through "density effects" (sensu Kordas et al., 2011), i.e. when interacting species respond differentially in terms of abundance to altered environmental conditions (Connell and Russell, 2010). Ocean acidification can also affect the per capita strength of an interaction ("per capita effects" sensu Kordas et al., 2011) if, for example, a consumer changes its food consumption in response to environmentally induced changes in prey palatability (Falkenberg et al., 2013b; Poore et al., 2013). Additionally, feeding rates and selectivity of consumers themselves may respond to ocean acidification. Assuming that food uptake of ectotherms scales with metabolic processes and given the profound effects of ocean acidification on various metabolic processes (Widdicombe and Spicer, 2008), consumption rates are likely influenced by ocean acidification either directly or indirectly through altered metabolic rates. Moreover, considering the complex interactive effects of ocean acidification and other environmental variables on biological processes (Harvey et al., 2013) feeding rates of herbivores will probably not only scale with $\mathrm{pCO}_{2}$ but also depend on variations in other factors. 
Many marine benthic herbivores are sensitive to variations in the palatability of their algal food. The palatability of a seaweed is determined by structural (e.g., tissue toughness) and chemical (e.g., elemental composition, defense chemicals) tissue characteristics which can vary in response to changing environmental conditions (Hemmi and Jormalainen, 2002; Long et al., 2013). Compared to animal tissue, algal tissue has a higher carbon content and relatively low contents of nitrogen and phosphorous. Thus, algae are a stoichiometrically imbalanced food for herbivores. Elevated carbon supply can shift the stoichiometry of marine primary producers towards higher $\mathrm{C}: \mathrm{N}$ and $\mathrm{C}: \mathrm{P}$ ratios, thereby further decreasing the nutritional quality for herbivores (Urabe et al., 2003; van de Waal et al., 2010). Herbivores can compensate for low levels of essential nutrients in their food by increasing consumption (Lincoln et al., 1986). Surplus carbon can then be removed metabolically, e.g. through enhanced respiration (Darchambeau et al., 2003). Elevated consumption of carbon enriched algal tissue is, thus, a possible mechanism for how ocean acidification might affect the per capita interaction strength between marine herbivores and seaweeds. In addition to the elemental composition chemical herbivore deterrents, such as phlorotannins, are important determinants of seaweed palatability (Poore, 1994). However, the sensitivity for chemical defenses varies among grazer species (Pavia and Toth, 2000) and the effects of ocean acidification on the phlorotannin content of seaweeds are inconsistent (Olischläger et al., 2012; Swanson and Fox, 2007). Accordingly, the effects of ocean acidification on the nutritional quality of seaweeds and, thus, on the interaction between seaweeds and their consumers are largely unpredictable.

The brown seaweed Fucus vesiculosus is an important component of rocky shore ecosystems in the temperate North Atlantic. The species forms dense inter- and shallow subtidal canopies and provides extensive habitat and food for a great variety of species (Wikström and Kautsky, 2007). Additionally, floating sporophytes of $F$. vesiculosus in coastal waters serve as dispersal vector for the seaweed itself and for numerous associated rafting organisms (Vandendriessche et al., 2006). An important consumer of $F$. vesiculosus is the herbivorous isopod Idotea baltica which uses the alga not only as food but also as habitat, shelter from predators and as a dispersal vector (Franke et al., 1999; Vesakoski et al., 2008). Recent studies on trophic interactions between I. baltica and $F$. vesiculosus showed that the palatability of the seaweed changes with environmental conditions (e.g. eutrophication) and that the isopods are sensitive to variations in the nutritional quality of the alga (Hemmi and Jormalainen, 2002; Honkanen et al., 2002). We used F. vesiculosus and its consumer I. baltica as a model system to study potential effects of ocean acidification on the trophic interaction between seaweeds and herbivores. We conducted $\mathrm{CO}_{2}$ perturbation experiments to test the following hypotheses: (1) Ocean acidification enhances growth of $F$. vesiculosus. (2) Elevated $\mathrm{CO}_{2}$ levels increase the C:N and C:P ratios of $F$. vesiculosus tissue. (3) I. baltica displays different consumption rates on algae that have been grown at different $\mathrm{CO}_{2}$ levels. (4) I. baltica shows elevated respiration rates when fed with $F$. vesiculosus that has been grown at elevated $\mathrm{CO}_{2}$ levels than on algae grown under ambient $\mathrm{CO}_{2}$ conditions. Additionally, we tested (5) the effects of ocean acidification on the consumption rates of herbivores for $F$. vesiculosus and (6) whether ocean acidification interacts with temperature in its effect on the consumption rate of the herbivore. For the latter experiments we used the isopod Idotea emarginata as consumer, which is a common rafter on floating $F$. vesiculosus in the North Sea (Franke et al., 1999; Gutow and Franke, 2003).

\section{Material and methods}

To allow for sufficient replication the first experiment on $F$. vesiculosus and I. baltica was performed in two consecutive sets of sub-experiments due to logistical constraints. The first sub-experiment was started in late winter (February 2010) and the second in early spring (March 2010).

\subsection{Cultivation of algae}

F. vesiculosus was collected on the island of Helgoland in the German Bight, North Sea $\left(54^{\circ} 10^{\prime} 39^{\prime \prime} N, 7^{\circ} 53^{\prime} 45^{\prime \prime}\right.$ E). Non-reproductive apical thallus tips (length: $>2 \mathrm{~cm}$; wet weight (WW): 0.15-0.18 g) without visible epiphytes were haphazardly cut off from thalli growing on a sheltered rocky harbor jetty. The tips were transferred into $10 \mathrm{~L}$ glass bottles (43 cm height; $20 \mathrm{~cm}$ diameter) which were filled with sterile filtered $(0.02 \mu \mathrm{m})$ North Sea water and subjected to one of two $\mathrm{CO}_{2}$ treatments: $280 \mu$ atm (i.e. pre-industrial atmospheric $\mathrm{CO}_{2}$ level; Feely et al., 2004) and $700 \mu \mathrm{atm}$ (i.e. predicted atmospheric $\mathrm{CO}_{2}$ levels by the end of the 21st century; Caldeira and Wickett, 2005), respectively. The $\mathrm{CO}_{2}$ partial pressure $\left(\mathrm{pCO}_{2}\right)$ of the seawater was adjusted by continuous incubation with $\mathrm{CO}_{2}$-enriched artificial air (80\% nitrogen, 20\% oxygen; gas-mixer: HTK Hamburg $\mathrm{GmbH}$, Germany) through air stones at a continuous gas supply rate of about $0.2 \mathrm{~L} \mathrm{~min}^{-1}$ bottle ${ }^{-1}$. Probably due to the metabolic activity of the algae and potentially associated micro-organisms (the cultures were non-axenic) the actual $\mathrm{pCO}_{2}$ of the seawater medium deviated from the target values (Table 1 ). Accordingly, the two treatments are hereafter referred to as low and high $\mathrm{pCO}_{2}$, respectively. Each bottle received 16 algal tips. Six replicate bottles were set up for each $\mathrm{CO}_{2}$ concentration. The bottles were covered with glass lids to reduce evaporation.

The algae were transferred in two steps from the cold winter conditions in the field to the experimental temperature of $10{ }^{\circ} \mathrm{C}$. After three days at $5{ }^{\circ} \mathrm{C}$, the replicate bottles with the tips were transferred to a culture room of $10{ }^{\circ} \mathrm{C}$ where each sub-experiment ran for four weeks at a light/dark rhythm of $\mathrm{L}: \mathrm{D}=16: 8 \mathrm{~h}$. The glass bottles were illuminated with cool-white fluorescent tubes (Osram, L36W/954; Munich, Germany) with a light intensity of $70 \mu \mathrm{mol}$ photons $\mathrm{m}^{-2} \mathrm{~s}^{-2}$ at the bottom of the bottles and $100 \mu \mathrm{mol}$ photons $\mathrm{m}^{-2} \mathrm{~s}^{-2}$ at their surface (LI-185B with a LI-190SB quantum sensor, LI-COR® Biosciences, Lincoln, USA). In the field, $F$. vesiculosus experiences light intensities of up to $500 \mu \mathrm{mol}$ photons $\mathrm{m}^{-2} \mathrm{~s}^{-2}$ while severe light-limitation of the species occurs below the light-compensation point of about $20 \mu \mathrm{mol}$ photons $\mathrm{m}^{-2} \mathrm{~s}^{-2}$ (Weinberger et al., 2011). No additional nutrients were added to the seawater. The total biomass (WW) of all algal pieces in each bottle was measured five times during the culturing period and divided by the number of algal tips per bottle to calculate the average biomass of the algal tips. The average growth rate $\left(\mathrm{mg}_{w w} \mathrm{~d}^{-1}\right)$ of the tips was calculated from the slope of linear biomass increase (see Section 2.).

\section{Table 1}

Carbonate system of the seawater medium in which apical tips of Fucus vesiculosus and individuals of Idotea emarginata were cultured. Algae were cultured at low and high $\mathrm{pCO}_{2}$ (incubated at 280 and $700 \mu \mathrm{atm}$, respectively) in two consecutive sub-experiments. Isopods were cultured at combinations of two different $\mathrm{pCO}_{2}$ (incubated at 280 and $1200 \mu \mathrm{atm}$, respectively) and two temperatures ( 10 and $15^{\circ} \mathrm{C}$ ). Data are mean $\pm \mathrm{SD}$.

\begin{tabular}{|c|c|c|c|c|}
\hline \multirow[t]{2}{*}{ Fucus vesiculosus } & \multicolumn{2}{|c|}{ 1st sub-experiment } & \multicolumn{2}{|c|}{ 2nd sub-experiment } \\
\hline & Low $\mathrm{pCO}_{2}$ & High pCO ${ }_{2}$ & Low $\mathrm{pCO}_{2}$ & High pCO 2 \\
\hline pH (NBS-scale) & $8.32 \pm 0.09$ & $7.99 \pm 0.06$ & $8.29 \pm 0.06$ & $7.94 \pm 0.06$ \\
\hline Salinity & $31.9 \pm 0.1$ & $32.7 \pm 0.1$ & $31.8 \pm 0.1$ & $32.1 \pm 0.2$ \\
\hline Total alkalinity & $2415 \pm 17$ & $2436 \pm 55$ & $2448 \pm 51$ & $2464 \pm 23$ \\
\hline $\mathrm{pCO}_{2}(\mu \mathrm{atm})$ & $282 \pm 71$ & $656 \pm 101$ & $305 \pm 53$ & $754 \pm 118$ \\
\hline $\mathrm{CO}_{2}$ & $13 \pm 3$ & $29 \pm 4$ & $14 \pm 2$ & $34 \pm 5$ \\
\hline $\mathrm{CO}_{3}^{-}$ & $184 \pm 29$ & $99 \pm 13$ & $176 \pm 19$ & $89 \pm 11$ \\
\hline $\mathrm{HCO}_{3}^{2-}$ & $1965 \pm 75$ & $2294 \pm 53$ & $2019 \pm 82$ & $2247 \pm 35$ \\
\hline \multirow[t]{2}{*}{ Idotea emarginata } & \multicolumn{2}{|l|}{$10^{\circ} \mathrm{C}$} & \multicolumn{2}{|l|}{$15^{\circ} \mathrm{C}$} \\
\hline & Low $\mathrm{pCO}_{2}$ & High pCO ${ }_{2}$ & Low $\mathrm{pCO}_{2}$ & High pCO ${ }_{2}$ \\
\hline $\mathrm{pH}$ (total scale) & $7.86 \pm 0.05$ & $7.51 \pm 0.06$ & $7.88 \pm 0.05$ & $7.47 \pm 0.09$ \\
\hline Salinity & $33.3 \pm 0.2$ & $33.4 \pm 0.2$ & $33.3 \pm 0.1$ & $33.5 \pm 0.2$ \\
\hline Total alkalinity & $2442 \pm 42$ & $2454 \pm 50$ & $2403 \pm 87$ & $2450 \pm 64$ \\
\hline $\mathrm{pCO}_{2}(\mu \mathrm{atm})$ & $383 \pm 53$ & $1021 \pm 189$ & $456 \pm 73$ & $1368 \pm 309$ \\
\hline $\mathrm{CO}_{2}$ & $17 \pm 2$ & $45 \pm 8$ & $17 \pm 3$ & $52 \pm 12$ \\
\hline $\mathrm{CO}_{3}^{-}$ & $151 \pm 16$ & $70 \pm 9$ & $153 \pm 18$ & $67 \pm 13$ \\
\hline $\mathrm{HCO}_{3}^{2-}$ & $2072 \pm 42$ & $2283 \pm 59$ & $2025 \pm 83$ & $2286 \pm 64$ \\
\hline
\end{tabular}


To avoid accumulation of metabolites and nutrient depletion, the medium was exchanged every 2-3 days throughout the entire experimental period. Before seawater exchange, freshly filtered North Sea water (salinity: 31-32) was incubated at the respective target $\mathrm{pCO}_{2}$ for at least $24 \mathrm{~h}$ before it was used in the experiments. The $\mathrm{pH}$ (NBS scale) (WTW720 WTW-GmbH, Weilheim, Germany, equipped with an IoLine-electrode, SI-analytics GmbH, Mainz, Germany) and the salinity (WTW-LF 197-S, WTW-GmbH, Weilheim, Germany) of the seawater were measured once a week before the medium was exchanged. Before seawater exchange a $250 \mathrm{~mL}$ seawater sample from each replicate bottle was collected in brown borosilicate flasks for determination of total alkalinity. The total alkalinity of the seawater was determined in subsamples of $25 \mathrm{~mL}$ by potentiometric titration (Gran, 1952) using a computer controlled automated titration system (TitroLine ${ }^{\circledR}$ alpha plus; equipped with a SCHOTT ${ }^{\circledR}$ Instruments IoLine IL-MICRO-pH-ADIN pH electrode, SI Analytics GmbH, Mainz, Germany) and the software package Titrisoft 2.60 (SI Analytics GmbH, Mainz, Germany). The components of the seawater carbonate system were calculated from $\mathrm{pH}$, total alkalinity and salinity with the MS Excel-AddIn CO2sys (Lewis and Wallace, 1998) using the equilibrium constants for the dissociation of carbonic acid in seawater from Mehrbach et al. (1973) refit by Dickson and Millero (1987) and by Dickson (1990) for $\mathrm{KSO}_{4}$.

\subsubsection{Elemental composition of algal tissue}

For the feeding assays (described in the next section), the proximal $2 \mathrm{~cm}$ of the tips, which had been produced in the field, were cut off so that the isopods received only the distal sections which were grown at the respective $\mathrm{pCO}_{2}$. The distal section of one algal tip from each bottle (i.e., six replicates per $\mathrm{pCO}_{2}$ and sub-experiment) was cut longitudinally in two halves. One half was offered to an isopod in the feeding assay. The other half was further divided into three equal longitudinal sections which were stored at $-30{ }^{\circ} \mathrm{C}$ for later determination of the $\mathrm{C}, \mathrm{N}$ and $\mathrm{P}$ contents.

For the determination of the $\mathrm{C}$ and $\mathrm{N}$ contents, the algal fragments were dried at $60{ }^{\circ} \mathrm{C}$ for $24 \mathrm{~h}$ and stored for $\sim 1$ week in an exsiccator. Before further processing, the tissue was again lyophilized, pulverized in liquid nitrogen and weighed to the nearest $0.01 \mathrm{mg}$. $\mathrm{C}$ and $\mathrm{N}$ contents (\% DW) were determined in subsamples of 0.01-0.02 mg (Carlo Erba NA-1500 elemental analyzer) against an acetanilide standard. The total P content of the pieces was determined after Grasshoff et al. (1983) from 0.01 to $0.02 \mathrm{gww}_{\mathrm{ww}}$ of algal material after drying $\left(60^{\circ} \mathrm{C}\right.$ for $24 \mathrm{~h}$ ) and grinding in a mortar. The elemental ratios were expressed as molar ratios.

\subsection{Herbivore food consumption}

I. baltica were taken from cultures where the isopods were kept in a continuously aerated non-flow-through seawater system at $10{ }^{\circ} \mathrm{C}$ and a light/dark rhythm of $\mathrm{L}: \mathrm{D}=12: 12 \mathrm{~h}$. The natural North Sea water was exchanged twice a week. Brown algae (Ascophyllum nodosum and F. vesiculosus) were offered as food.

The average ( \pm SD) biomass of the isopods used in the no-choice feeding assays was $0.25 \pm 0.05 \mathrm{~g}_{\mathrm{ww}}$ for the first sub-experiment and $0.44 \pm 0.07 \mathrm{~g}_{w w}$ for the second sub-experiment. The isopods were maintained individually in plastic cups (volume: $100 \mathrm{~mL}$ ) with $60 \mathrm{~mL}$ of ambient, filtered $(0.02 \mu \mathrm{m})$ seawater. The feeding assays were conducted at summer conditions of $15{ }^{\circ} \mathrm{C}$ and a light/dark rhythm of $12: 12$ $\mathrm{h}$ to stimulate the feeding activity of the isopods. Prior to the feeding assay the isopods were starved for $24 \mathrm{~h}$ to remove all gut content. Subsequently (still prior to the start of the assay), the isopods were fed for two days distal sections of the tips of $F$. vesiculosus that were grown at low and high $\mathrm{pCO}_{2}$, respectively. During these two days, the algal food was renewed daily.

For the feeding assays, the remaining half of the longitudinally cut distal sections of the algal tips (see previous section) was weighed (WW) and offered to each of six replicate isopods for $24 \mathrm{~h}$ for the determination of the ingestion rate. The initial biomass of the algal pieces ranged from 0.10 to $0.18 \mathrm{~g}_{\mathrm{ww}}$. Six similarly treated algal pieces (one from each bottle) were weighed and maintained individually under the same conditions for $24 \mathrm{~h}$ without grazer as control for autogenic weight change. At the end of the feeding assay the isopods and the remaining algal pieces were weighed. The daily (the experiments ran for $24 \mathrm{~h}$ ) consumption rates of the isopods were calculated as $\mathrm{C}=\mathrm{W}_{\mathrm{i}} *\left(\mathrm{C}_{\mathrm{f}} / \mathrm{C}_{\mathrm{i}}\right)-\mathrm{W}_{\mathrm{f}}$ (Cronin and Hay, 1996) and related to the biomass of the grazer. $W_{i}$ and $W_{f}$ are the initial and the final $W W$ of the algal tissue, respectively, and $C_{i}$ and $C_{f}$ are the equivalent $W W$ of the control pieces.

\subsection{Herbivore respiration}

After the feeding assays, the isopods were kept individually in $60 \mathrm{~mL}$ glass cups for another day feeding on $F$. vesiculosus from the same $\mathrm{CO}_{2}$-treatment used during the feeding assay. Prior to the determination of the respiration rates, the isopods were kept for $12 \mathrm{~h}$ without food for defecation. Oxygen consumption rates of the isopods were determined by the Winkler method (Grasshoff et al., 1983). Filtered $(0.2 \mu \mathrm{m})$ seawater was adjusted overnight to the experimental temperature of $15{ }^{\circ} \mathrm{C}$ and filled into incubation bottles $(0.608 \pm 0.007 \mathrm{~L})$. Each respiration chamber was equipped with a $1 \mathrm{~cm}^{2}$ piece of gauze for the isopods to cling to. After the isopods had been respiring in the incubation bottles for 6-7 h, sub-samples of the seawater were transferred into Winkler flasks (50-60 mL) and fixed for the quantification of dissolved oxygen following the procedures described by Grasshoff et al. (1983). Four bottles were run as controls without isopods. Dissolved oxygen in each sub-sample was measured in triplicates. At the end of the experiments the isopods were weighed, dried at $60{ }^{\circ} \mathrm{C}$ for $24 \mathrm{~h}$ and combusted at $500{ }^{\circ} \mathrm{C}$ for $12 \mathrm{~h}$ for the determination of dry weight (DW) and ash free dry weight (AFDW).

\subsection{Effects of temperature and $\mathrm{CO}_{2}$ on herbivore food consumption}

I. emarginata were taken from laboratory cultures that were run under the same conditions as described above for I. baltica. Male I. emarginata were kept individually in $400 \mathrm{~mL}$ glass beakers in one out of four possible combinations of two $\mathrm{pCO}_{2}(280$ and $1200 \mu \mathrm{atm})$ and two temperatures $\left(10\right.$ and $15{ }^{\circ} \mathrm{C}$ ) (Table 1$)$. The isopods received freshly collected pieces of $F$. vesiculosus which were exchanged every day. The experiments were conducted in temperature controlled rooms at a light-dark regime of $\mathrm{L}: \mathrm{D}=16: 8$. The carbonate chemistry of the seawater was adjusted following the same procedures as described above for the incubation of $F$. vesiculosus. Again, the actual seawater carbonate chemistry deviated from the desired target conditions probably due to the animals' metabolism (Table 1). Therefore, the treatments will be referred to as low and high $\mathrm{pCO}_{2}$, respectively. The seawater was exchanged every day and the seawater carbonate chemistry was documented every 2-3 days again following the same procedures as described above for the incubation of $F$. vesiculosus, with the exception that the seawater $\mathrm{pH}$ was expressed on the total scale. The total $\mathrm{pH}$ was determined from subsamples of the $250 \mathrm{~mL}$ seawater samples. The electromotive force of the seawater and of Tris-buffer seawater standards (Oceanic Carbon Dioxide Control, Scripps Institution of Oceanography, San Diego, CA, USA) was measured at $25{ }^{\circ} \mathrm{C}$. The total $\mathrm{pH}(\mathrm{pH} \mathrm{t})$ was calculated as follows:

$\mathrm{pH} t=\mathrm{pH}(\mathrm{S})+\frac{\mathrm{E}(\mathrm{s})-\mathrm{E}(\mathrm{x})}{\mathrm{RT} \ln 10 / \mathrm{F}}$

with $\mathrm{pH}(\mathrm{S})=\mathrm{pH}$ of the seawater standard, $\mathrm{E}(\mathrm{s})$ and $\mathrm{E}(\mathrm{x})$ being the electromotive force of the seawater standard and the seawater sample, respectively, $\mathrm{R}=$ gas constant, $\mathrm{T}=$ temperature $(\mathrm{K})$, and $\mathrm{F}=$ Faraday constant (Dickson et al., 2007).

After 12 days of culturing, ten replicate isopods (biomass: $0.056-0.601$ $\mathrm{g}_{\mathrm{ww}}$ ) were used from each of the four $\mathrm{pCO}_{2}$-temperature combinations 
for feeding assays. The isopods received freshly collected pieces of F. vesiculosus which were weighed (WW) prior to and at the end of the $24 \mathrm{~h}$ feeding period. The initial biomass of the algal pieces offered to the isopods ranged from 0.133 to $0.274 \mathrm{~g}$. For each treatment, ten control pieces (WW range: 0.129-0.284 g) each were kept under the same conditions without grazers to determine the autogenic weight change of the algal pieces. The WW of the isopods was also measured at the end of the feeding period and the consumption rates were calculated using the equation by Cronin and Hay (1996) and related to the body mass of the isopods.

\subsection{Statistical analysis}

Growth of $F$. vesiculosus over the culturing period was analyzed by linear regression. The growth rate $\left(\mathrm{mg}_{\mathrm{ww}} \mathrm{d}^{-1}\right)$ of an average algal piece was estimated for each bottle from the slope of the specific linear regression line. Growth rates and elemental ratios (C:N, C:P, N:P) of $F$. vesiculosus as well as consumption and respiration rates of $I$. baltica were tested for treatment effects using 2-factorial ANOVA with the two factors " $\mathrm{pCO}_{2}$ " (two factor levels) and "sub-experiment" (two factor levels). Consumption rates of I. emarginata were tested for treatment effects using two-factorial ANOVA with the two factors " $\mathrm{pCO}_{2}$ " (two factor levels) and "temperature" (two factor levels). Prior to ANOVA the data were tested for homogeneity of variances using Levene's test. In case of heteroscedasticity, the data were ln-transformed. All statistical analyses were performed with the software STATISTICA 7.1 (StatSoft Inc., Tulsa, USA).

\section{Results}

\subsection{Algal growth}

The algal tips grew linearly in both $\mathrm{CO}_{2}$-treatments. The linear regression model explained $87-95 \%$ of the variation. The growth rate of $F$. vesiculosus, calculated over the whole experimental period, was significantly higher at low $\mathrm{pCO}_{2}$ than at high $\mathrm{pCO}_{2}\left(\mathrm{~F}_{1,20}=11.17, \mathrm{p}<0.01\right.$; Fig. 1). At low $\mathrm{pCO}_{2}$, the average ( $\pm \mathrm{SEM}$ ) growth rate of the algal tips was $14.4 \pm 0.5 \mathrm{~g}_{w w} \mathrm{~d}^{-1}$ and $13.0 \pm 1.5 \mathrm{~g}_{w w} \mathrm{~d}^{-1}$ in the first and in the second sub-experiment, respectively. At the high $\mathrm{pCO}_{2}$, the average growth rate was $10.4 \pm 0.5 \mathrm{~g}_{w w} \mathrm{~d}^{-1}$ in the first and $11.0 \pm 0.6 \mathrm{~g}_{w w} \mathrm{~d}^{-1}$ in the second sub-experiment. The algal tips had similar growth rates in the first and in the second sub-experiment $\left(\mathrm{F}_{1,20}=0.24, \mathrm{p}=0.63\right)$. There was no interactive effect of $\mathrm{pCO}_{2}$ and the timing of the sub-experiment on the growth of $F$. vesiculosus $\left(\mathrm{F}_{1,20}=1.19, \mathrm{p}=0.29\right)$. Accordingly, the data from the two sub-experiments were combined in Fig. 1.

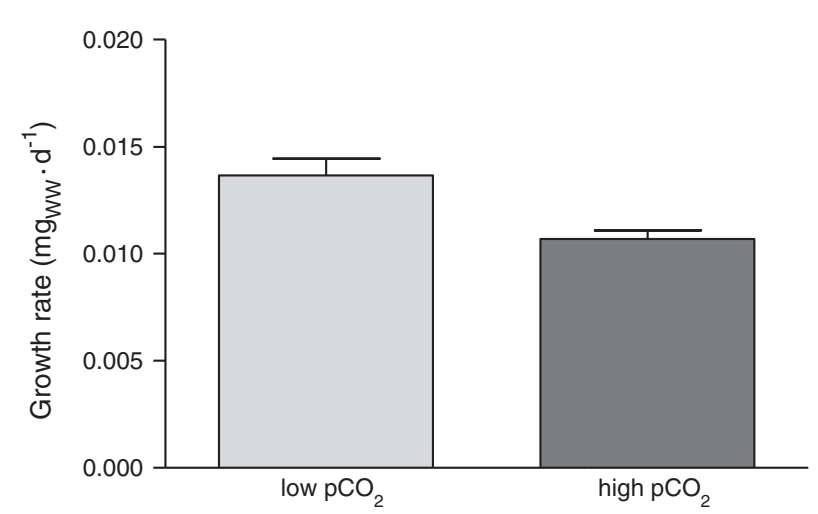

Fig. 1. Fucus vesiculosus: growth rates of apical thallus tips at low and high $\mathrm{pCO}_{2}$ (incubated at 280 and $700 \mu \mathrm{atm}$, respectively). The growth rates were similar in the two consecutive sub-experiments and the data were, therefore, combined in the figure. Growth was significantly reduced at high $\mathrm{pCO}_{2}$. Data are mean $\pm \operatorname{SEM}(n=12)$.

\subsection{Elemental composition of algal tissue}

The $\mathrm{C}: \mathrm{N}$ ratio of $\mathrm{F}$. vesiculosus was significantly reduced by the high $\mathrm{pCO}_{2}\left(\mathrm{~F}_{1,20}=4.59, \mathrm{p}=0.04\right.$; Fig. 2). At the low $\mathrm{pCO}_{2}$ the $\mathrm{C}: \mathrm{N}$ ratio ranged from 16.8 to 35.9 while at the high $\mathrm{pCO}_{2}$ the ratio varied between 18.2 and 28.1. The $\mathrm{C}: \mathrm{N}$ ratio of the algae did not differ between the two sub-experiments $\left(\mathrm{F}_{1,20}=2.67, \mathrm{p}=0.12\right) \cdot \mathrm{pCO}_{2}$ and the timing of the sub-experiment had no interactive effect on the $\mathrm{C}: \mathrm{N}$ ratio of the algae $\left(\mathrm{F}_{1,20}=0.05, \mathrm{p}=0.83\right)$.

The C:P ratio of $F$. vesiculosus was not affected by the $\mathrm{pCO}_{2}$ $\left(\mathrm{F}_{1,20}<0.01, \mathrm{p}=0.98\right)$ and ranged between 304.0 and 1808.5 (Fig. 2). The C:P ratio did not vary between the two sub-experiments $\left(\mathrm{F}_{1,20}=3.28, \mathrm{p}=0.09\right)$. For the $\mathrm{C}: \mathrm{P}$ ratio the two main factors did not interact $\left(\mathrm{F}_{1,20}=0.02, \mathrm{p}=0.90\right)$.

The N:P ratio of $F$. vesiculosus was also independent of the $\mathrm{pCO}_{2}$ $\left(F_{1,20}=0.43, p=0.52\right)$ and did not vary between the two subexperiments $\left(\mathrm{F}_{1,20}=4.08, \mathrm{p}=0.06\right.$; Fig. 2$)$. Again, the two main factors did not interact $\left(\mathrm{F}_{1,30}=0.04, \mathrm{p}=0.84\right)$. The $\mathrm{N}: \mathrm{P}$ ratio of the algae ranged between 12.0 and 69.4 .

The average molar C:N:P ratios of $F$. vesiculosus were 669:29:1 and 696:24:1 for the low and the high $\mathrm{pCO}_{2}$-treatment, respectively, in the first sub-experiment, and 1007:25:1 and 991:21:1 for the low and the high $\mathrm{pCO}_{2}$-treatment, respectively, in the second sub-experiment (Fig. 2). Since the ratios were similar between the two sub-experiments the data were combined in Fig. 2.

\subsection{Herbivore food consumption}

The consumption rates did not differ between isopods that were feeding on algae from different $\mathrm{CO}_{2}$ treatments $\left(\mathrm{F}_{1,20}=0.01\right.$, $\mathrm{p}=0.91)$. However, I. baltica consumed more algal tissue in the first than in the second sub-experiment $\left(F_{1,20}=11.45, \mathrm{p}<0.01\right.$; Fig. 3). The consumption rates varied between 0.02 and 0.34 $g_{w w} \cdot g_{w w} \cdot d^{-1}$ in the first sub-experiment and between 0.04 and $0.31 \mathrm{~g}_{w w} \cdot \mathrm{g}_{\mathrm{ww}} \cdot \mathrm{d}^{-1}$ in the second sub-experiment. The $\mathrm{pCO}_{2}$ and the timing of the sub-experiment did not interactively affect the consumption rate of $I$. baltica $\left(\mathrm{F}_{1,20}=1.58, \mathrm{p}=0.22\right)$.

\subsection{Herbivore respiration}

The oxygen consumption of I. baltica varied between 0.92 and $3.92 \mathrm{mg} \mathrm{O}_{2} \mathrm{~g}_{\mathrm{AFDW}}^{-1} \mathrm{~h}^{-1}$. Isopods feeding on $F$. vesiculosus from different $\mathrm{pCO}_{2}$-treatments had similar respiration rates $\left(\mathrm{F}_{1,20}=0.56, \mathrm{p}=0.46\right.$; Fig. 4). The isopods also had similar respiration rates in both subexperiments $\left(\mathrm{F}_{1,20}=0.40, \mathrm{p}=0.54\right)$. In the first sub-experiment the respiration rate was slightly higher in isopods that had been feeding

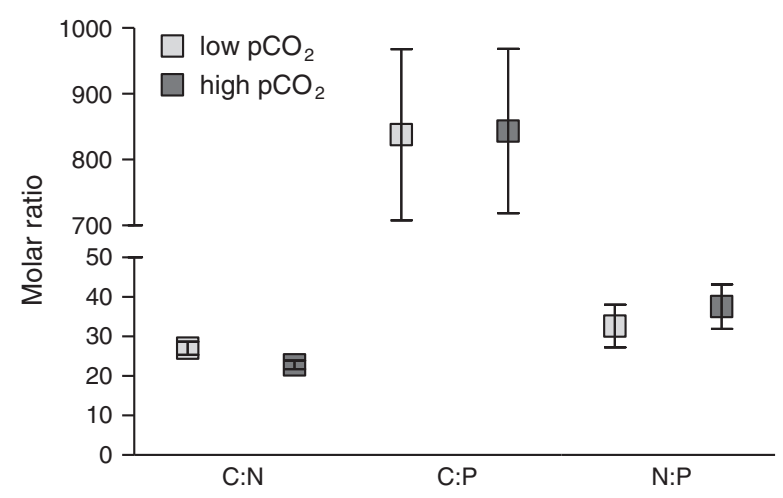

Fig. 2. Fucus vesiculosus: molar ratios of $\mathrm{C}: \mathrm{N}, \mathrm{C}: \mathrm{P}$ and $\mathrm{N}: \mathrm{P}$ of apical thallus tips cultured at low or high $\mathrm{pCO}_{2}$ (incubated at 280 and $700 \mu$ atm, respectively). Elemental ratios were similar in the two consecutive sub-experiments and the data were, therefore, combined in the figure. The $\mathrm{C}: \mathrm{N}$ ratio was significantly reduced at high $\mathrm{pCO}_{2}$. Data are mean \pm SEM $(\mathrm{n}=12)$. 


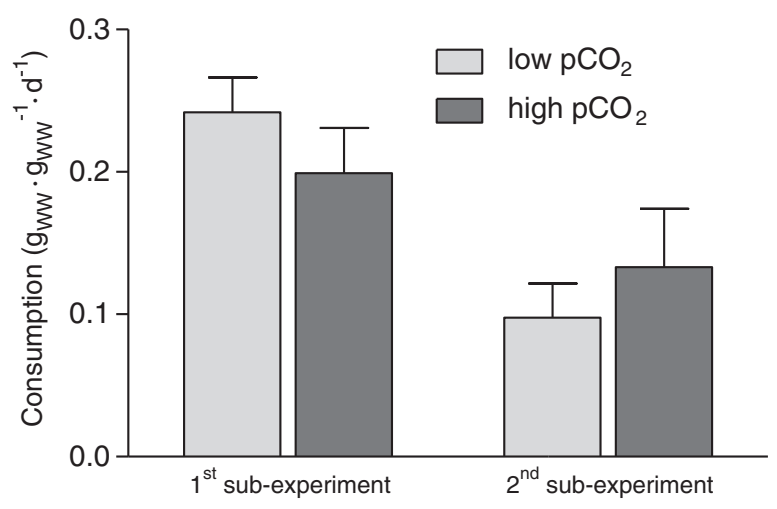

Fig. 3. Idotea baltica: consumption rates of the isopods on Fucus vesiculosus that had been growing at either low or high $\mathrm{pCO}_{2}$ (incubated at 280 and $700 \mu \mathrm{atm}$, respectively) in two consecutive sub-experiments. Consumption rates were significantly higher in the first sub-experiment. Data are mean $\pm \operatorname{SEM}(n=6)$.

on algae from the low $\mathrm{pCO}_{2}$ while in the second sub-experiment the isopods consumed more oxygen when feeding on algae from the high $\mathrm{CO}_{2}$ treatment resulting in an interactive effect of the two main factors on the respiration rate of the isopods $\left(F_{1,20}=5.23, p=0.03\right)$.

\subsection{Effects of temperature and $\mathrm{CO}_{2}$ on herbivore food consumption}

I. emarginata that had been maintained at low and high $\mathrm{pCO}_{2}$, respectively, had similar feeding rates on $F$. vesiculosus $\left(\mathrm{F}_{1,36}=2.86\right.$, $\mathrm{p}=0.10$; Fig. 5). Similarly, temperature had no effect on the feeding rates of the isopods $\left(\mathrm{F}_{1,36}=2.43, \mathrm{p}=0.13\right) . \mathrm{CO}_{2}$ and temperature did not interactively affect the feeding rates of $I$. emarginata $\left(\mathrm{F}_{1,36}=3.98\right.$, $\mathrm{p}=0.05)$. The average $( \pm \mathrm{SEM})$ consumption rate of $I$. emarginata was $0.14 \pm 0.02 \mathrm{~g} \mathrm{~g}^{-1} \mathrm{~d}^{-1}$.

\section{Discussion}

Elevated $\mathrm{CO}_{2}$ levels lowered the $\mathrm{C}: \mathrm{N}$ ratio of $F$. vesiculosus. However, the changes in the elemental composition had no effect on the nutritional quality of the algae for the herbivorous isopod I. baltica. The isopods had similar consumption rates on algae that had been grown at different $\mathrm{pCO}_{2}$. Moreover, the consumption rate of the isopod I. emarginata on $F$. vesiculosus was largely independent of $\mathrm{pCO}_{2}$ and temperature. Hence, the results of our $\mathrm{CO}_{2}$ perturbation experiments gave no indication for changes in the per capita strength of the interaction between $F$. vesiculosus and its isopod consumers. However, growth of F. vesiculosus was reduced at elevated $\mathrm{CO}_{2}$ levels. This might lead to

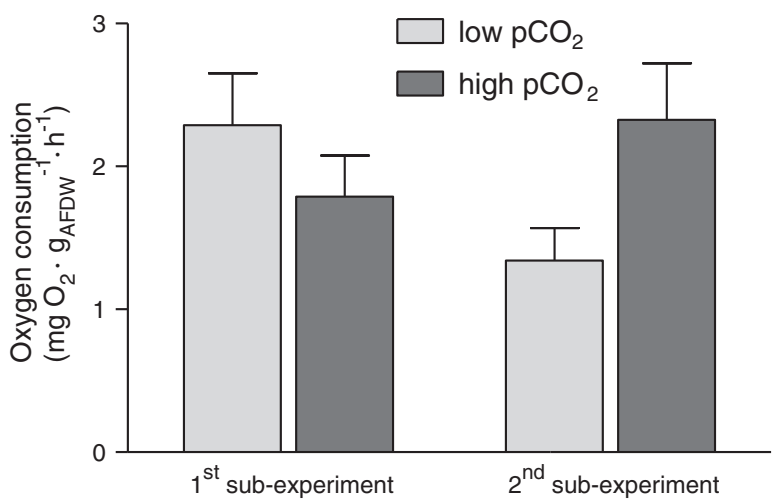

Fig. 4. Idotea baltica: respiration rates of isopods that had been feeding on Fucus vesiculosus grown at either low or high $\mathrm{pCO}_{2}$ (incubated at 280 and $700 \mu$ atm, respectively) in two consecutive sub-experiments. $\mathrm{pCO}_{2}$ and the timing of the sub-experiments had a significant interactive effect on the oxygen consumption of the isopods. Data are mean \pm SEM $(n=6)$.

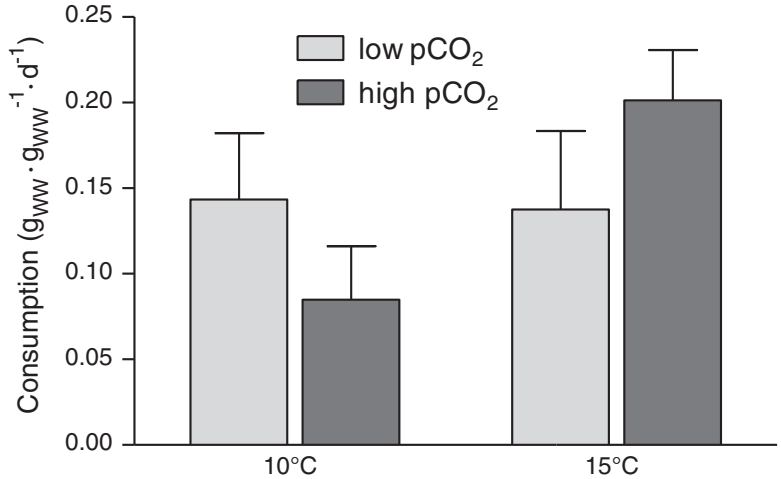

Fig. 5. Idotea emarginata: consumption rates of isopods that had been cultured for twelve days at combinations of high and low $\mathrm{pCO}_{2}$ (incubated at 280 and $1200 \mu \mathrm{tm}$, respectively) and two temperatures $\left(10\right.$ and $\left.15^{\circ} \mathrm{C}\right)$ on Fucus vesiculosus. Data are mean $\pm \operatorname{SEM}(\mathrm{n}=10)$

density effects if populations of consumers or competitors of the seaweed remain unaffected or benefit from ocean acidification.

\subsection{Growth of F. vesiculosus}

Non-calcifying autotrophic organisms are expected to benefit from enhanced $\mathrm{CO}_{2}$ supply for photosynthesis and, in fact, examples exist for marine algae and seagrasses that grow faster at elevated $\mathrm{pCO}_{2}$ (Olischläger and Wiencke, 2013; Olischläger et al., 2013; Sarker et al., 2013; Swanson and Fox, 2007; Zimmermann et al., 1997). Accordingly, non-calcifying seaweeds are suggested to largely benefit from the changes in seawater carbonate chemistry (Kroeker et al., 2010, 2013) although the reactions of seaweeds to ocean acidification are variable (Olischläger et al., 2012; Swanson and Fox, 2007). The low sensitivity of many seaweed species to elevated $\mathrm{CO}_{2}$ availability has been explained by the existence of an enzymatic carbon concentrating mechanism (CCM) that allows for the acquisition of carbon from the vast pool of bicarbonate in seawater which is virtually unlimited under current conditions and even more so under enhanced levels of ocean acidification (Israel and Hophy, 2002; Raven et al., 2011). In addition to the CCM, seaweeds of the genus Fucus possess an internal organic carbon pool which makes the algae even more independent of external $\mathrm{CO}_{2}$ fluctuations (Kawamitsu and Boyer, 1999). In clear contradiction to our hypothesis, growth of $F$. vesiculosus was reduced by about 10 to $15 \%$ at elevated $\mathrm{CO}_{2}$ levels. Negative effects of ocean acidification on growth have been observed in other seaweed species as well. For example, growth of the red alga Porphyra linearis was inhibited at seawater $\mathrm{pH}$ $<8.0$ (Israel et al., 1999) possibly due to the $\mathrm{pH}$ sensitivity of the specific CCM of Porphyra species (Moulin et al., 2011). Similarly, growth of the kelp Saccharina latissima was substantially lower at a high $\mathrm{pCO}_{2}$ of $1300 \mu \mathrm{atm}$ than at ambient $\mathrm{CO}_{2}$ levels (Swanson and Fox, 2007). The authors suggested that $S$. latissima was negatively affected by ocean acidification because the CCM of this species allows for optimal photosynthesis at high seawater $\mathrm{pH}$ (Axelsson et al., 2000). Growth of marine algae does not only depend on the availability of $\mathrm{CO}_{2}$ but also on other environmental variables such as nutrients (Xu et al., 2010) and irradiance levels (Sarker et al., 2013). Interactive effects of $\mathrm{CO}_{2}$ and other parameters might influence the responses and, thus, complicate the prediction of implications of ocean acidification for seaweeds.

\subsection{Nutritional quality of F. vesiculosus}

Xu et al. (2010) showed that carbon utilization of the red alga Gracilaria lemaneiformis was enhanced at high $\mathrm{pCO}_{2}$ while nitrogen uptake decreased. Poore et al. (2013) did not detect effects of ocean acidification on the elemental composition of the brown alga Sargassum linearifolium. However, the herbivorous amphipod Peramphithoe parmerong consumed more $S$. linearifolium at elevated $\mathrm{pCO}_{2}$ when the 
algae were simultaneously exposed to elevated temperatures indicating interactive effects of ocean acidification and warming on the palatability of the algae (Poore et al., 2013). In our experiments, high $\mathrm{pCO}_{2}$ led to a decreased C:N ratio of $F$. vesiculosus. However, consumption rates of I. baltica were independent of the algal treatment, indicating that the altered elemental composition did not change the nutritional quality of $F$. vesiculosus for the herbivores. In field based mesocosm experiments in an Australian kelp forest ocean acidification led to an elevated nitrogen content in small turf algae (Falkenberg et al., 2013b). Falkenberg et al. (2013a) suggested that a more efficient photosynthesis at high $\mathrm{pCO}_{2}$ might allow algae to re-allocate nitrogen to other metabolic processes resulting in a higher tissue $\mathrm{N}$-content. In contrast to our results the elevated nitrogen content of the turf algae stimulated the consumption by the herbivorous gastropod Austrocochlea concamerata (Falkenberg et al., 2013b). Our results indicate that ocean acidification alone is not able to change the nutritional quality of $F$. vesiculosus for I. baltica. However, the two-factorial (ocean acidification and temperature) experiment by Poore et al. (2013) as well as the study by Falkenberg et al. (2013b), which was conducted under variable field conditions, indicate that interactions between ocean acidification and other environmental parameters are able to influence the palatability of seaweeds in ways that changes the per capita interaction strength between algae and their consumers. A similar interaction of ocean acidification with other environmental factors became evident from the interactive effect of $\mathrm{pCO}_{2}$ and the timing of the sub-experiments on the respiration rate of $I$. baltica. The two consecutive sub-experiments were conducted under identical conditions. Accordingly, the environmental factor, which interacted with the $\mathrm{pCO}_{2}$, could not be identified from our experimental approach but might have been associated with seasonal processes occurring in $F$. vesiculosus between the two field sampling campaigns.

\subsection{Food consumption of I. emarginata}

Many crustaceans are expected to be largely insensitive to ocean acidification (Kroeker et al., 2010, 2013; Whiteley, 2011). Nevertheless, examples exist of the effects of ocean acidification on the performance of marine crustaceans. Growth and survival of the amphipod Gammarus locusta were not affected by ocean acidification (Hauton et al., 2009). However, the authors could show responses of the amphipods to elevated $\mathrm{pCO}_{2}$ in terms of gene expression. Poore et al. (2013) showed that growth and survival of the amphipod P. parmerong were negatively affected by ocean acidification and high seawater temperatures, but the temperature effects were more pronounced than the $\mathrm{CO}_{2}$ effects. Food consumption of $P$. parmerong was independent of $\mathrm{pCO}_{2}$. Similarly, Falkenberg et al. (2013b) excluded direct effects of ocean acidification on the consumption rates of herbivorous gastropods. In agreement with the results from these previous studies, food consumption did not vary with $\mathrm{pCO}_{2}$ in $I$. emarginata, the other isopod species used in our study. These results indicate that possible negative effects of ocean acidification on small herbivorous crustaceans, such as enhanced amphipod mortality observed by Poore et al. (2013), are probably not related to processes that could be compensated by enhanced food consumption.

Temperature also did not affect the consumption rate of I. emarginata. Metabolic theory predicts that food assimilation in ectotherms increases with temperature to meet enhanced metabolic demands. However, previous studies indicate that other factors such as body size and food availability are better determinants of consumption rates of marine herbivores than temperature (Hillebrand et al., 2009; Saiz and Calbet, 2011). Accordingly, clear evidence for a positive correlation between temperature and feeding rates is still lacking for small benthic marine herbivores. Feeding rates of the amphipod Ampithoe longimana varied stronger at elevated temperatures but did not show a clear increase (O'Connor, 2009). Similarly, food consumption of P. parmerong was independent of temperature (Poore et al., 2013). Solely the medium sized herbivorous gastropod Tegula spp. showed enhanced feeding rates on seaweeds at elevated temperatures (Yee and Murray, 2004).

The interactive effect of ocean acidification and temperature on the consumption rate of $I$. emarginata was close to significant. At low $\mathrm{pCO}_{2}$, feeding rates of the isopods were similar at both temperatures. At high $\mathrm{pCO}_{2}$, however, elevated temperatures apparently stimulated (though not significantly) the food uptake indicating that elevated $\mathrm{CO}_{2}$ concentrations may increase the temperature sensitivity of the isopods. This would be in agreement with the findings by Walther et al. (2009), who observed that ocean acidification can affect the thermal tolerance of a marine crustacean. Together these results indicate that in interaction with rising seawater temperature ocean acidification may be able to affect not only metabolic processes of single individuals but also complex consumer-prey interactions.

\subsection{Conclusion}

In our experiments ocean acidification did not clearly affect the per capita interaction strength between the seaweed $F$. vesiculosus and the herbivores I. baltica and I. emarginata. Interactive effects with other environmental variables remain to be tested for this algae-grazer system. Reduced growth of $F$. vesiculosus under conditions of ocean acidification might reduce the capacity of the seaweed to compensate for intense herbivory, potentially resulting in smaller standing biomass of this species.

In our experiments the thallus pieces of $F$. vesiculosus were permanently submerged in the culture medium. In the North Sea, however, $F$. vesiculosus lives in the intertidal and might thus benefit from regular tidal emergence as other intertidal species do (Madsen and Maberly, 1990). Accordingly, permanent submergence might make intertidal algae more susceptible to ocean acidification. In the field $F$. vesiculosus frequently becomes detached from the substratum, for example after storm events, and floats at the sea surface where the algae do not experience regular tidal emergence. Ocean acidification will, thus, have implications for the growth of floating $F$. vesiculosus. Associated herbivores continuously graze upon floating algae thereby accelerating the decomposition of algal rafts (Rothäusler et al., 2009; Vandendriessche et al., 2007). Raft decomposition can be partly compensated by algal growth. However, if algal growth is reduced by ocean acidification while the consumption of herbivores remains unaffected, the decomposition of algal rafts might be accelerated under future conditions. This could have implications for the dispersal of $F$. vesiculosus and for species that rely on algal rafting, for example for connectivity of coastal populations.

\section{Acknowledgments}

The valuable comments of two anonymous reviewers greatly improved the manuscript. We acknowledge financial support from the German Federal Ministry of Education and Research (BMBF; grant no. 03F0608B).[SS]

\section{References}

Alsterberg, C., Eklöf, J.S., Gamfeldt, L., Havenhand, J.N., Sundbäck, K., 2013. Consumers mediate the effects of experimental ocean acidification and warming on primary producers. Proc. Natl. Acad. Sci. U. S. A. 110, 8603-8608.

Axelsson, L., Mercado, J., Figueroa, F., 2000. Utilization of $\mathrm{HCO}_{3}^{-}$at high $\mathrm{pH}$ by the brown macroalga Laminariasaccharina. Eur. J. Phycol. 35, 53-59.

Caldeira, K., Wickett, M.E., 2005. Ocean model predictions of chemistry changes from carbon dioxide emissions to the atmosphere and ocean. J. Geophys. Res. 110, C09S04.

Chan, N.C.S., Conolly, S.R., 2013. Sensitivity of coral calcification to ocean acidification: a meta-analysis. Glob. Change Biol. 19, 282-290.

Connell, S.D., Russell, B.D., 2010. The direct effects of increasing $\mathrm{CO}_{2}$ and temperature on non-calcifying organisms: increasing the potential for phase shifts in kelp forests. Proc. R. Soc. Ser. B 277, 1409-1415.

Cronin, G., Hay, M.E., 1996. Induction of seaweed chemical defenses by amphipod grazing. Ecology 77, 2287-2301.

Darchambeau, F., Faerøvig, P.J., Hessen, D.O., 2003. How Daphnia copes with excess carbon in its food. Oecologia 136, 336-346. 
Dickson, A.G., 1990. Standard potential of the reaction: $\mathrm{AgCl}(\mathrm{s})+\mathrm{H} 2(\mathrm{~g})=\mathrm{Ag}(\mathrm{s})+$ $(\mathrm{HCl})(\mathrm{aq})$, and the standard acidity constant of the ion HSO4 - in synthetic sea water from 273.15 to 318.15 K. J. Chem. Thermodyn. 22, 113-127.

Dickson, A.G., Millero, F., 1987. A comparison of the equilibrium constants for the dissociation of carbonic acid in seawater media. Deep Sea Res. 34, 1733-1743.

Dickson, A.G., Sabine, C.L., Christian, J.R. (Eds.), 2007. Guide to best practices for ocean $\mathrm{CO}_{2}$ measurements. Special Publication, 3. PICES, Sidney.

Falkenberg, L.J., Russell, B.D., Connell, S.D., 2013a. Contrasting resource limitations of marine primary producers: implications for competitive interactions under enriched $\mathrm{CO}_{2}$ and nutrient regimes. Oecologia 172, 575-583.

Falkenberg, L.J., Russell, B.D., Connell, S.D., 2013b. Future herbivory: the indirect effects of enriched $\mathrm{CO}_{2}$ may rival its direct effects. Mar. Ecol. Prog. Ser. 492, 85-95.

Feely, R.A., Sabine, C.L., Lee, K., Berelson, W., Kleypas, J., Fabry, V.J., Millero, F.J., 2004. Impact of anthropogenic $\mathrm{CO}_{2}$ on the $\mathrm{CaCO}_{3}$ system in the oceans. Science 305, 362-366.

Franke, H.-D., Gutow, L., Janke, M., 1999. The recent arrival of the oceanic isopod Idotea metallica Bosc off Helgoland (German Bight, North Sea): an indication of a warming trend in the North Sea? Helgoländer Meeresun. 52, 347-357.

Gran, G., 1952. Determination of the equivalence point in potentiometric titrations. Part II. Analyst 77, 661-671.

Grasshoff, K., Ehrhardt, M., Kremlin, K., 1983. Methods of Seawater Analysis. Second, Revised and Extended Version. Verlag Chemie, Weinheim (419 pp.).

Gutow, L., Franke, H.-D., 2003. Metapopulation structure of the marine isopod Idoted metallica, a species associated with drifting habitat patches. Helgoland Mar. Res. 56, 259-264.

Hall-Spencer, J.M., Rodolfo-Metalpa, R., Martin, S., Ransome, E., Fine, M., Turner, S.M., Rowley, S.J., Tedesco, D., Buia, M.-C., 2008. Volcanic carbon dioxide vents show ecosystem effects of ocean acidification. Nature 454, 96-99.

Harvey, B.P., Gwynn-Jones, D., Moore, P.J., 2013. Meta-analysis reveals complex marine biological responses to the interactive effects of ocean acidification and warming. Ecol. Evol. 3, 1016-1030.

Hauton, C., Tyrrell, T., Williams, J., 2009. The subtle effects of sea water acidification on the amphipod Gammarus locusta. Biogeosciences 6, 1479-1489.

Hemmi, A., Jormalainen, V., 2002. Nutrient enhancement increases performance of a marine herbivore via quality of its food alga. Ecology 83, 1052-1064.

Hillebrand, H., Borer, E.T., Bracken, M.E.S., Cardinale, B.J., Cebrian, J., Cleland, E.E. Elser, J.J., Gruner, D.S., Harpole, W.S., Ngai, J.T., Sandin, S., Seabloom, E.W., Shurin, J.B., Smith, J.E., Smith, M.D., 2009. Herbivore metabolism and stoichiometry each constrain herbivory at different organizational scales across ecosystems. Ecol. Lett. 12, 516-527.

Honkanen, T., Joemalainen, V., Hemmi, A., Mäkinen, A., Heikkila, N., 2002. Feeding and growth of the isopod Idotea baltica on the brown alga Fucus vesiculosus: roles of inter-population and within-plant variation in plant quality. Ecoscience 9, 332-338.

Hurd, C.L., Hepburn, C.D., Currie, K.I., Raven, J.A., Hunter, K.A., 2009. Testing the effects of ocean acidification on algal metabolism: considerations for experimental designs. J. Phycol. 45, 1236-1251.

Israel, A., Hophy, M., 2002. Growth, photosynthetic properties and Rubisco activities and amounts of marine macroalgae grown under current and elevated seawater $\mathrm{CO}_{2}$ concentrations. Glob. Change Biol. 8, 831-840.

Israel, A., Katz, S., Dubinsky, Z., Merrill, J.E., Friedlander, M., 1999. Photosynthetic inorganic carbon utilization and growth of Porphyra linearis (Rhodophyta). J. Appl. Phycol. 11, 447-453.

Kawamitsu, Y., Boyer, J.S., 1999. Photosynthesis and carbon storage between tides in a brown alga, Fucus vesiculosus. Mar. Biol. 133, 361-369.

Kordas, K.J., Harley, C.D.G., O'Connor, M.I., 2011. Community ecology in a warming world: the influence of temperature on interspecific interactions in marine systems. J. Exp. Mar. Biol. Ecol. 400, 218-226.

Kroeker, K.J., Kordas, R.L., Crim, R.N., Singh, G.G., 2010. Meta-analysis reveals negative yet variable effects of ocean acidification on marine organisms. Ecol. Lett. $13,1419-1434$.

Kroeker, K.J., Kordas, R.L., Crim, R., Hendriks, I.E., Ramajos, L., Singh, G.S., Duarte, C.M., Gattuso, J.-P., 2013. Impacts of ocean acidification on marine organisms: quantifying sensitivities and interaction with warming. Glob. Change Biol. 19, 1884-1896.

Lewis, E., Wallace, E.W.R., 1998. Program Developed for $\mathrm{CO}_{2}$ System Calculation. Carbon Dioxide Information Analysis Center, Oak Ridge National Laboratory, U.S. Department of Energy, Oak Ridge, TN.

Lincoln, D.E., Couvet, D., Sionit, N., 1986. Response of an insect herbivore to host plants grown in carbon dioxide enriched atmospheres. Oecologia 69, 556-560.

Long, J.D., Porturas, L., Jones, E., Kwan, C., Trussell, G.C., 2013. Seaweed traits linked to wave exposure determine predator avoidance. Mar. Ecol. Prog. Ser. 483, 143-151.

Madsen, S.C., Maberly, T.V., 1990. Contribution of air and water to the carbon balance of Fucus spiralis. Mar. Ecol. Prog. Ser. 62, 175-183.

Martin, S., Gattuso, J.-P., 2009. Response of Mediterranean coralline algae to ocean acidification and elevated temperature. Glob. Change Biol. 15, 2089-2100.

Mehrbach, C., Culberson, C.H., Hawley, J.E., Pytkowicz, R.M., 1973. Measurement of the apparent dissociation constants of carbonic acid in seawater at atmospheric pressure. Limnol. Oceanogr. 18, 897-907.
Moulin, P., Andría, J.R., Axelsson, L., Mercado, J.M., 2011. Different mechanisms of inorganic carbon acquisition in red macroalgae (Rhodophyta) revealed by the use of TRIS buffer. Aquat. Bot. 95, 31-38.

O'Connor, M.I., 2009. Warming strengthens an herbivore-plant interaction. Ecology 90, 388-398.

Olischläger, M., Wiencke, C., 2013. Ocean acidification alleviates low-temperature effects on growth and photosynthesis of the red alga Neosiphonia harveyi (Rhodophyta) J. Exp. Bot. 64, 5587-525.

Olischläger, M., Bartsch, I., Gutow, L., Wiencke, C., 2012. Effects of ocean acidification on different life-cycle stages of the kelp Laminaria hyperborea (Phaeophyceae). Bot Mar. 55, 511-525.

Olischläger, M., Bartsch, I., Gutow, L., Wiencke, C., 2013. Effects of ocean acidification on growth and physiology of Ulva lactuca (Chlorophyta) in a rockpool-scenario. Phycol. Res. 61, 180-190.

Pavia, H., Toth, G.B., 2000. Inducible chemical resistance to herbivory in the brown seaweed Ascophyllum nodosum. Ecology 81, 3212-3225.

Poore, A.G.B., 1994. Selective herbivory by amphipods inhabiting the brown alga Zonaria angustata. Mar. Ecol. Prog. Ser. 107, 113-123.

Poore, A.G.B., Graba-Landry, A., Favret, M., Brennand, H.S., Byrne, M., Dworjanyn, S.A 2013. Direct and indirect of ocean acidification and warming on a marine plantherbivore interaction. Oecologia 173, 1113-1124.

Pörtner, H.O., Langenbuch, M., Reipschläger, A., 2004. Biological impact of elevated ocean $\mathrm{CO}_{2}$ concentrations: lessons from animal physiology and earth history. J. Oceanogr. 60, 705-718.

Raven, J.A., Giordano, M., Beardall, J., Maberly, S.C., 2011. Algal and aquatic plant carbon concentrating mechanisms in relation to environmental change. Photosynth. Res. 109, 281-296.

Rothäusler, E., Gómez, I., Hinojosa, I.A., Tala, F., Thiel, M., 2009. Effect of temperature and grazing on growth and reproduction of floating Macrocystis spp. (Phaeophceae) along a latitudinal gradient. J. Phycol. 45, 547-559.

Saiz, E., Calbet, A., 2011. Copepod feeding in the ocean: scaling patterns, composition of their diet and the bias of estimates due to microzooplankton grazing during incubations. Hydrobiologia 666, 181-196.

Sarker, Md.Y., Bartsch, I., Olischläger, M., Gutow, L., Wiencke, C., 2013. Combined effects of $\mathrm{CO}_{2}$, temperature, irradiance and time on the physiological performance of Chondrus crispus (Rhodophyta). Bot. Mar. 56, 63-74.

Swanson, A.K., Fox, C.H., 2007. Altered kelp (Laminariales) phlorotannins and growth under elevated carbon dioxide and ultraviolet-B treatments can influence associated intertidal food webs. Glob. Change Biol. 13, 1696-1709.

Urabe, J., Togary, J., Elser, J.J., 2003. Stoichiometric impacts of increased carbon dioxide on a planktonic herbivore. Glob. Change Biol. 9, 818-825.

van de Waal, D.B., Verschoor, A.M., Verspagen, J.M.H., van Donk, E., Huisman, J., 2010 Climate-driven changes in the ecological stoichiometry of aquatic ecosystems. Front. Ecol. Environ. 8, 145-152.

Vandendriessche, S., Vincx, M., Degraer, S., 2006. Floating seaweed in the neustonic environment: a case study from Belgian coastal waters. J. Sea Res. 55, 103-112.

Vandendriessche, S., Vincx, M., Degraer, S., 2007. Floating seaweed and the influence of temperature, grazing and clump size on raft longevity - a microcosm study. J. Exp. Mar. Biol. Ecol. 343, 64-73.

Vesakoski, O., Boström, C., Ramsay, T., Jormalainen, V., 2008. Sexual and local divergence in host exploitation in the marine herbivore Idotea baltica (Isopoda). J. Exp. Mar. Biol. Ecol. 367, 118-126.

Walther, K., Sartoris, F.J., Bock, C., Pörtner, H.O., 2009. Impact of anthropogenic ocean acidification on thermal tolerance of the spider crab Hyas araneus. Biogeosci. Discuss. 6 , 2837-2861.

Weinberger, F., Rohde, S., Oschmann, Y., Shahnaz, L., Dobretsov, S., Wahl, M., 2001. Effects of limitation stress and of disruptive stress on induced antigrazing defense in the bladder wrack Fucus vesiculosus. Mar. Ecol. Prog. Ser. 427, 83-94.

Whiteley, N.M., 2011. Physiological and ecological responses of crustaceans to ocean acidification. Mar. Ecol. Prog. Ser. 430, 257-271.

Widdicombe, S., Spicer, J.I., 2008. Predicting the impact of ocean acidification on benthic biodiversity: what can animal physiology tell us? J. Exp. Mar. Biol. Ecol. 366, 187-197.

Wikström, S.A., Kautsky, L., 2007. Structure and diversity of invertebrate communities in the presence and absence of canopy-forming Fucus vesiculosus in the Baltic Sea. Estuar. Coast. Shelf Sci. 72, 168-176.

$\mathrm{Xu}, \mathrm{Z}$., Zou, D., Gao, K., 2010. Effects of elevated $\mathrm{CO}_{2}$ and phosphorus supply on growth photosynthesis and nutrient uptake in the marine macroalga Gracilaria lemaneiformis (Rhodophyta). Bot. Mar. 53, 123-129.

Yee, E.H., Murray, S.N., 2004. Effects of temperature on activity, food consumption rates, and gut passage times of seaweed-eating Tegula species (Trochidae) from California. Mar. Biol. 145, 895-903.

Zimmermann, R.C., Kohrs, D.G., Steller, D.L., Alberte, R.S., 1997. Impacts of $\mathrm{CO}_{2}$ enrichment on productivity and light requirements of eelgrass. Plant Physiol. 115, 599-607.

Zou, D., 2005. Effects of elevated atmospheric $\mathrm{CO}_{2}$ on growth, photosynthesis and nitrogen metabolism in the economic brown seaweed Hizikia fusiforme (Sargassaceae, Phaeophyta). Aquaculture 250, 726-735. 